\title{
25 years at the Kenneth Spencer Research Library
}

\author{
By Alexandra Mason
}

\section{Special Collections at the University of Kansas}

$\mathbf{T}$ he collecting of rare books and manuscripts at the University of Kansas, Lawrence, began within twenty years of the university's founding with the purchase by J.S. Crew \& Co. in June 1881 of Raleigh's History of the World in 5 Books (London, 1687)-for \$3.87-along with Johnson's The Lives of the Most Eminent English Poets (London, 1781)_-4 volumes at 63 cents each-and 30 other 18th-century English imprints. By August 1886, donations of rare books had begun with the gift of Pliny's Naturae bistoriarum libri xxxvii (Hagenoae, 1518) from William A. Phillips, a Scottish expatriate who had come to Kansas in 1855 as a special correspondent for the New York Tribune and stayed to found the city of Salina.

These early acquisitions-all of them except one of the 18th-century titles are still in the library despite having been in the general stacks for nearly 80 yearseventually became the nucleus of a rare books collection with natural history and the English 18th century as two of its strongest specialties.

Growth of the rare books collection proceeded slowly over the next three-quarters

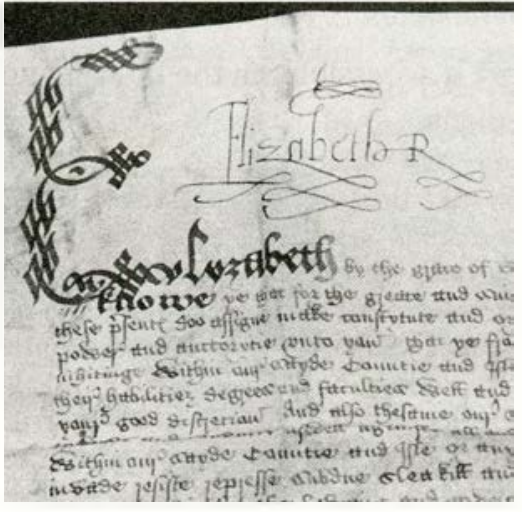

This is part of a document signed in 1559 by Elizabeth $I$ and contained in the Spencer Library's collections. quarters finally came in 1945 with the bequest by Ralph N. Ellis of his extraordinary collection of ornithological books and manuscripts. In 1953 the Department of Special Collections was established and its first curator, Joseph Rubinstein, was appointed to develop and care for the University's rare books and manuscripts.

Over the next 15 years the department far outgrew its first minimal quarters (a walled-off area of the stacks shared by collections, staff, and readers) and two other locations to which it moved in the main university library. Its staff increased from one to four, one of whom succeeded Rubinstein as head of the department in 1963. The collections grew to nearly 90,000 volumes. Through generous support from the university and donations of books, manuscripts, and funds from friends, the department continued to develop its special strengths while expanding into other areas.

The Ellis Collection (ornithology, other zoological history, exploration, and scientific expeditions) was joined by the Fitzpatrick botanical collection and a specialty in medicinal botany was established. A premier Linnaeus collection was formed from strong holdings in the Ellis and Fitzpatrick collections. With the establishment of the Summerfield Collection of early modern European printing (15th-17th centuries), the department was of a century. Impetus for the appointment of specialized staff and the provision of separate able to pursue collecting in the natural history of both the Old and New Worlds; develop 


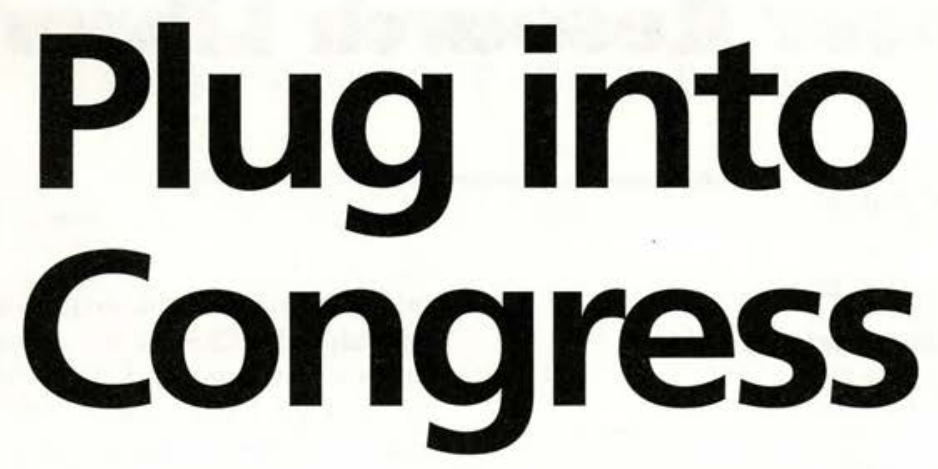

...With Washington Alert, the premier service for tracking congressional and state legislative and regulatory activity, created by Congressional Quarterly.

With more than 20 searchable databases including the full text of CQ publications, Washington Alert offers a remarkably detailed picture of Congress - ideal for a variety of groups at your institution, from government affairs administrators to students of political science.

There's no better way to track the issues - whether you're following the latest developments surrounding a bill or downloading a complete legislative chronology. No other one-stop resource offers such complete access to this fast-changing information.

Plus, Washington Alert is accessible via the Internet and offers a choice of flexible subscription plans.

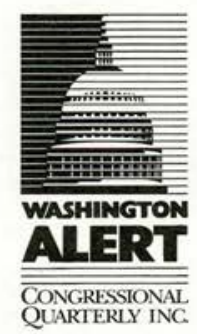

To find out more about Washington Alert and learn how you can obtain a free trial, contact Waldo Tibbetts at 1 (800) 432-2250 ext. 350. (In D.C., phone 887-6350), or internet WTIBBETTS@CQALERT.COM. 
strengths in political and economic history, law, ecclesiastical history, and Italian and Spanish literature; and build very strong holdings in the history of the book, particularly from the Stirling-Maxwell collection of Hispanic and Low Countries publications.

Eighteenth-century English imprints were joined by associated materials from other countries; for example, a substantial collection of French Revolutionary publications was added. Interest in Anglo-Irish literature and culture was developed by the acquisition of the Spoerri Collection of James Joyce, the P.S. O'Hegarty Yeats Collection, and later the O'Hegarty Collection of Irish history and culture.

Researchers from many de-

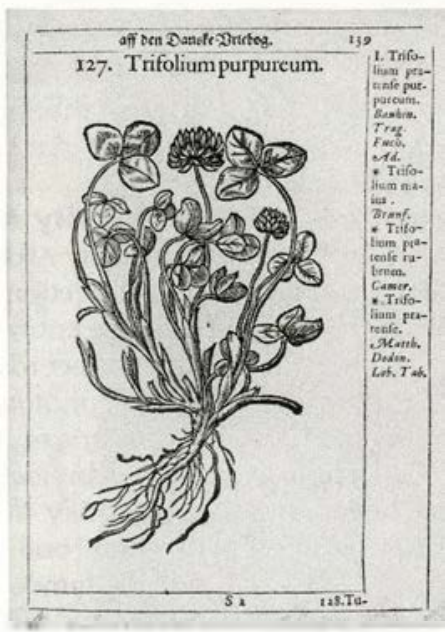

This illustration is from the book Flora danica by Simon Paulli (1648). partments in our university and from others across the United States began to seek the department out for its strengths and it began its long history of service to classroom teachers and individual students. One of the earliest student book collecting contests in the nation was established (and is still supported) by a generous donor. By the mid-1960s the basic needs of space for collections and readers could no longer be met in the main library and the need for better physical protection against environmental hazards and theft became pressing.

\section{The gift of a library}

At this time, Helen F. Spencer, a woman of vision and a philanthropist already distinguished for her support of the arts and humanities in the Kansas City area, decided to build a library at the University of Kansas as a memorial to her late husband Kenneth Spencer. The Kenneth Spencer Research Library-a 100,100square-foot library designed specifically to meet the needs of rare books, manuscripts, archives, and their users-was dedicated in November 1968 and opened to readers a month later. Mrs. Spencer remained a good friend to the Spencer Library until her death in 1982, visiting it frequently and demonstrating lively interest in its development.

Since the move to the Spencer Library, the researchers and students we serve have come to include the international scholarly commu- nity as well as the faculty, students, and residents of Kansas. The collections of the three Spencer departments-Special Collections, the Kansas Collection, and University Archives-have continued to grow, developing their first interests and entering upon new ones.

\section{Special Collections}

The Department of Special Collections is now 200,000 volumes strong, with the focus of uncommon materials in 18 thcentury British studies, especially periodicals and newspapers; the history of science, especially ornithology, medieval and early modern medicinal botany, Linnaeus, and scientific expeditions; Renaissance and early modern politics, economics, history, and travel; the histories of cartography and law; 16th- and 17thcentury Polonica; Irish 18th- to 20th-century literature and history; the French Revolution; Frank Lloyd Wright; medieval and early modern grammar; modern British and American literature (the pre-Raphaelites, Tennyson, Whitman, Yeats, Joyce, 20th-century American poetry); children's books and penny dreadfuls; 16th-century Italian literature; 18th-century French drama; American and international science fiction; and 19th-century Guatemalan imprints.

Its manuscripts (in nearly 2,000 collections) provide rich resources for research in Italian 16 th- and 17 th-century business and family archives; 16th-century reports of papal legates; political, economic, literary, and social history of 17th-century England and Ireland; 19th-century English letters; authors' archives in some minor genres of 20th-century American literature; English economic and social history of the 12th to the early 19th centuries as shown in legal papers of the periods; 19th-century natural history illustration. Over 1,000 bound volumes of manuscripts provide source material for research in medieval history and history of science, travel, and women's studies, in addition to the subjects previously mentioned.

\section{The Kansas Collection}

The Kansas Collection was begun in the 1890 s by the university's first librarian, Carrie Wat- 
son, to collect Kansas imprints and the history of Kansas. By the mid-1960s the Kansas Collection was a very strong local history collection, with such rarities as Jotham Meeker imprints and ephemeral publications from across the state. It had been named an official Kansas state publications depository and was acting as an unofficial University Archives. The collection was heavily used by students and local residents, and shared all the housing problems of the Department of Special Collections.

The Kansas Collection now contains regional history materials from roughly 1850 to the present, reflecting the economic, cultural, social, and political history of Kansas and the Kansas region, including the Wilcox Collection of Contemporary Political Movements begun as a collection of 1960 s Kansas radical publication

\section{Anniversary celebrations}

The Kenneth Spencer Research Library at the University of Kansas (KU), Lawrence, will observe the 25th anniversary of its opening with a triple exhibition. Each of the three departments of the library will mount an exhibition devoted to showing its own particular strengths and activities. The University Archives will display university records concerned with the establishment of the library itself. The Kansas Collection will showcase its activities in preserving, both by collection and by conservation, the heritage of Kansas. The Department of Special Collections exhibition, "Finders \& Keepers," will honor the donors, booksellers, collectors, scholars, librarians, and others who have built, supported, cared for, and used the collections. Each book or manuscript shown will be related to the "finders" and "keepers" in its history. An illustrated catalog will be published.

The formal celebration will take place in the spring of 1994 . The exhibitions will be opened with a reception in the afternoon on April 15 and John T. Casteen, president of the University of Virginia, will speak at a gala dinner hosted by the KU Friends of the Library that evening.

In connection with the anniversary, a fund drive is being undertaken for the purpose of supporting future exhibitions and publications. but now expanded to document left- and rightwing activity nationwide. The departmental holdings include over 100,000 printed volumes, nearly 10,000 linear feet of manuscript materials, a million and a half historical photographs, large numbers of maps, architectural drawings, and material in other media.

\section{University Archives}

University Archives—originally part of the Kansas Collection and officially established as a separate entity in 1969-houses official and unofficial records of the university, with another million photographs, including one of the largest American archives of sports photographs.

The building of collections is the basic responsibility of a library like ours but it is not the only one. Service to researchers, internationally famous scholars, or young students just beginning their intellectual lives takes precedence over everything else in the day-to-day work of our staff. The students and researchers are, after all, the reason the collections exist.

\section{Service to the library's patrons}

Our subject specialists teach classes and give lectures in the same subject areas which they develop through our acquisitions program; they select books and manuscripts for faculty to use in their courses and provide assistance with research. Our curator of manuscripts helps researchers with manuscripts and teaches students to read the handwriting of the past. Our conservator advises enquirers on the care of their own books and helps them deal with damaged books. We teach a course in the history of the book and act as a museum of the book, teaching our students to understand the meaning of books and, through our exhibition program, illustrating and publicizing our resources. To make our collections known far outside our own campus, we contribute records of our cataloging to national and international bibliographical databases.

The development of such a resource library here in Kansas has been made possible by the encouragement and gifts of the university and its friends. We are confident that, with the help of generous friends, the challenges of the future-new research interests, new methods, new forms of evidence-will be met as the Kenneth Spencer Research Library continues its mission of support to humanistic research and teaching and the discovery and interpretation of the past. 


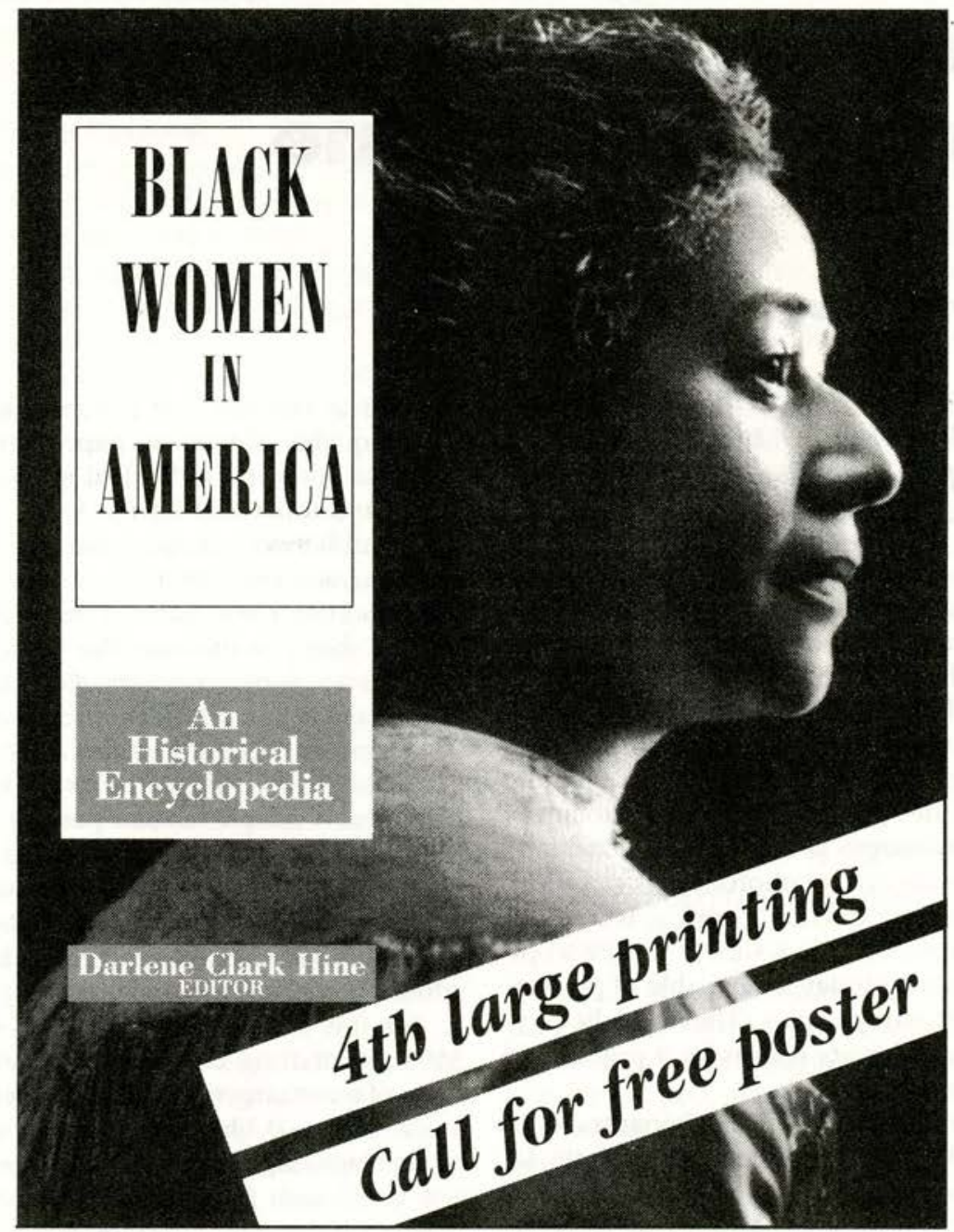

“. . . a standard reference source for years to come. Highly recommended for all libraries."

\section{Choice}

For information about discounts and to request a splendid

$$
\text { FREE POSTER }
$$

call toll-free 1-800-336-7460

or write CARLSON PUBLISHING, INC.;

P.O. Box 023350; Brooklyn, New York 11202 